\title{
Genetic origin and salinity history influence the reproductive success of Atlantic herring
}

\author{
Florian Berg ${ }^{1,2, *}$, Aril Slotte ${ }^{2}$, Leif Andersson ${ }^{3,4,5}$, Arild Folkvord ${ }^{1,2}$ \\ ${ }^{1}$ University of Bergen, Department of Biological Sciences, Post Box 7803, 5020 Bergen, Norway \\ ${ }^{2}$ Institute of Marine Research (IMR), Post Box 1870 Nordnes, 5018 Bergen, Norway \\ ${ }^{3}$ Science for Life Laboratory, Department of Medical Biochemistry and Microbiology, Uppsala University, SE-751 23 Uppsala, \\ Sweden \\ ${ }^{4}$ Department of Animal Breeding and Genetics, Swedish University of Agricultural Sciences, SE-750 07 Uppsala, Sweden \\ ${ }^{5}$ Department of Veterinary Integrative Biosciences, Texas A\&M University, College Station, Texas 77843-4458, USA
}

\begin{abstract}
Atlantic herring populations inhabit environments ranging in salinity from fully marine to nearly freshwater, but their relative reproductive success in these respective environments remains unclear. We conducted factorial crossing experiments using parents from 3 wild populations associated with different salinity environments: the Baltic Sea ( 6 psu), an inland brackish lake in Norway (Landvikvannet, $\sim 16 \mathrm{psu}$ ), and the Atlantic ( 30 to $35 \mathrm{psu}$ ). Further experiments used crosses within and between Atlantic purebreds and Atlantic/Baltic hybrids reared until first maturity at $3 \mathrm{yr}$ of age. Crossing experiments were conducted at 6, 16 and $35 \mathrm{psu}$. Fertilization and hatching rates were estimated, and egg sizes were measured. Fertilization rates were highest at 16 psu for all combinations. The paternal genetic and salinity origin influenced fertilization rates at 6 and $35 \mathrm{psu}$, indicating a genetic adaptation to their original environment. Fertilization rates for males originating from 16 psu were low at 35 psu. Atlantic/Baltic hybrids had lower fertilization rates than Atlantic purebreds at 35 psu. Hatching rates were not influenced by any parental factors or salinity. Maternal effects and salinity influenced egg size. Atlantic females had significantly larger eggs than the Atlantic/Baltic hybrid females. For all genetic groups, egg size decreased with increasing salinity at incubation mainly due to osmotic effects. The observed lower fertilization success at salinities other than those of the parental fish habitat would have evolutionary consequences when herring colonize new habitats with different salinities or if interbreeding occurred between populations originating from different salinity habitats.
\end{abstract}

KEY WORDS: Common garden - Fertilization experiment - Salinity · Clupea harengus · Reproduction $\cdot$ Egg size $\cdot$ Connectivity

\section{INTRODUCTION}

Marine environments have relatively few physical barriers limiting the connectivity of fish populations. For marine fish, the ability to rapidly adapt to new environments is necessary to colonise new habitats (Schneider \& Meyer 2017). The colonization of freshwater from marine environments was a huge evolutionary transition (Lee et al. 2011). Extreme low-

${ }^{*}$ Corresponding author: florian.berg@uib.no

${ }^{\S}$ Advance View was available online September 6, 2018 salinity marine habitats may harbour highly adapted populations, but as a consequence those populations may have lost genetic diversity during the adaptation process (Johannesson \& André 2006).

The Baltic Sea is an example of a boundary environment that has changed since it was formed $10000 \mathrm{yr}$ ago following the last glaciation (Andrén et al. 2011). A strong salinity gradient occurs throughout the Baltic Sea from the inner Bothnian Bay (2 to

(C) The authors 2019. Open Access under Creative Commons by Attribution Licence. Use, distribution and reproduction are unrestricted. Authors and original publication must be credited. 
$3 \mathrm{psu}$ ) to the opening near the fully marine North Sea/Atlantic Ocean (35 psu). Several marine species in the Baltic live near the limits of their physiological tolerance and are highly adapted and genetically different from populations in the North Sea/Atlantic Ocean (Nilsson et al. 2001, Martinez Barrio et al. 2016). Adaptations of such Baltic Sea populations compensate for the general negative impact of low salinity on the reproduction and development of marine fish (Nissling et al. 2006). Examples of adaptations to the Baltic Sea include changes in egg buoyancy (Nissling \& Westin 1997), genetic variants of haemoglobin (Andersen et al. 2009), and altered spectral tuning mechanisms of visual pigments (Larmuseau et al. 2010).

Atlantic herring Clupea harengus has one of the highest economic and ecological values of all fish species in the northeast Atlantic Ocean and the Baltic Sea. The distinct genetic differences between herring from the Atlantic and Baltic at hundreds of loci (Lamichhaney et al. 2012, Martinez Barrio et al. 2016) support the separation into 2 subspecies: Baltic herring $C$. harengus membras and Atlantic herring $C$. harengus harengus. The 2 subspecies show very similar levels of genetic diversity, and they share the same genetic factors associated with timing of reproduction despite marked genetic differences at loci controlling the adaptation to the Baltic Sea environment (Lamichhaney et al. 2017). Also, the population structure of Atlantic herring can be complex (Iles \& Sinclair 1982) ranging from migratory oceanic populations to stationary local populations. Some of these populations can be genetically distinguished (Bekkevold et al. 2007, Pampoulie et al. 2015). Further, populations within the Baltic Sea are structured according to the salinity gradient (Bekkevold et al. 2005, Jørgensen et al. 2005). Mixing of different populations occurs, within and between the populations of the 2 subspecies, but the level of connectivity is still unclear (Gröhsler et al. 2013, Eggers et al. 2014, Johannessen et al. 2014).

Herring are total spawners with adhesive demersal eggs. Fertilization is possible in salinities ranging from 0 psu (distilled water; Klinkhardt 1984) up to 50 psu or more (Holliday \& Blaxter 1960). However, it is unknown to what extent adaptations to different salinities affect the capacity for successful fertilization in a broad range of salinities. In addition, there are varying degrees of reproductive investment between migratory (oceanic), semi-stationary (coastal), and stationary (local) populations (Silva et al. 2013). Migratory populations typically have lower relative fecundity and smaller eggs than stationary popula- tions (Silva et al. 2013, dos Santos Schmidt et al. 2017). Environmental factors, like salinity, also affect the size of spawned herring eggs (Holliday \& Blaxter 1960), with potential effects on subsequent larval growth (Blaxter \& Hempel 1963).

Life-history traits such as fertilization, hatching success, and egg size were examined experimentally to investigate adaptation of the different parental groups. We aimed to address 3 issues: (1) the extent to which herring originating from different salinities can interbreed, (2) the effect of salinity conditions on reproductive success, and (3) the influence of the originating environment of parental groups on the relative reproductive success in different salinities. Further, egg sizes were analysed to evaluate different strategies in reproductive investment of parental fish of different genetic and environmental backgrounds. We conducted several fertilization experiments to test the adaptation of Atlantic herring to different salinity conditions. We used herring from 3 wild populations that are assumed to be adapted to marine (30-35 psu, Atlantic), brackish (16 psu, Landvikvannet), and low salinity (6 psu, Baltic) conditions. Finally, we used Atlantic herring and the first filial (F1) generation of Atlantic/Baltic hybrids, hereafter called purebreds and hybrids, co-reared in captivity during their entire life in different salinity conditions, either 35 or $16 \mathrm{psu}$, as parental fish to evaluate cross-generation environmental effects of second generation (F2) reared offspring fitness. Notably, this is the first study to report characteristics of experimentally produced F2 herring offspring.

\section{MATERIALS AND METHODS}

\subsection{Factorial crossing experiments}

Five factorial crossing experiments were conducted using Atlantic herring Clupea harengus from 3 wild populations and 2 distinct genetic groups of laboratory-reared herring (Fig. 1). Spawning herring were sampled at different locations, and the respective fertilization experiments were conducted within $14 \mathrm{~h}$ after capture at the University of Bergen. Each experiment included within-group crosses. For some experiments, additional between-group crosses were conducted in a fully reciprocal design. Several combinations, i.e. pairs of fish, were fertilized per cross. The fertilization of each combination was conducted separately at 3 salinities, 6, 16 and 35 psu, except Expt 1 and partly Expt 2 where all fertilizations were 


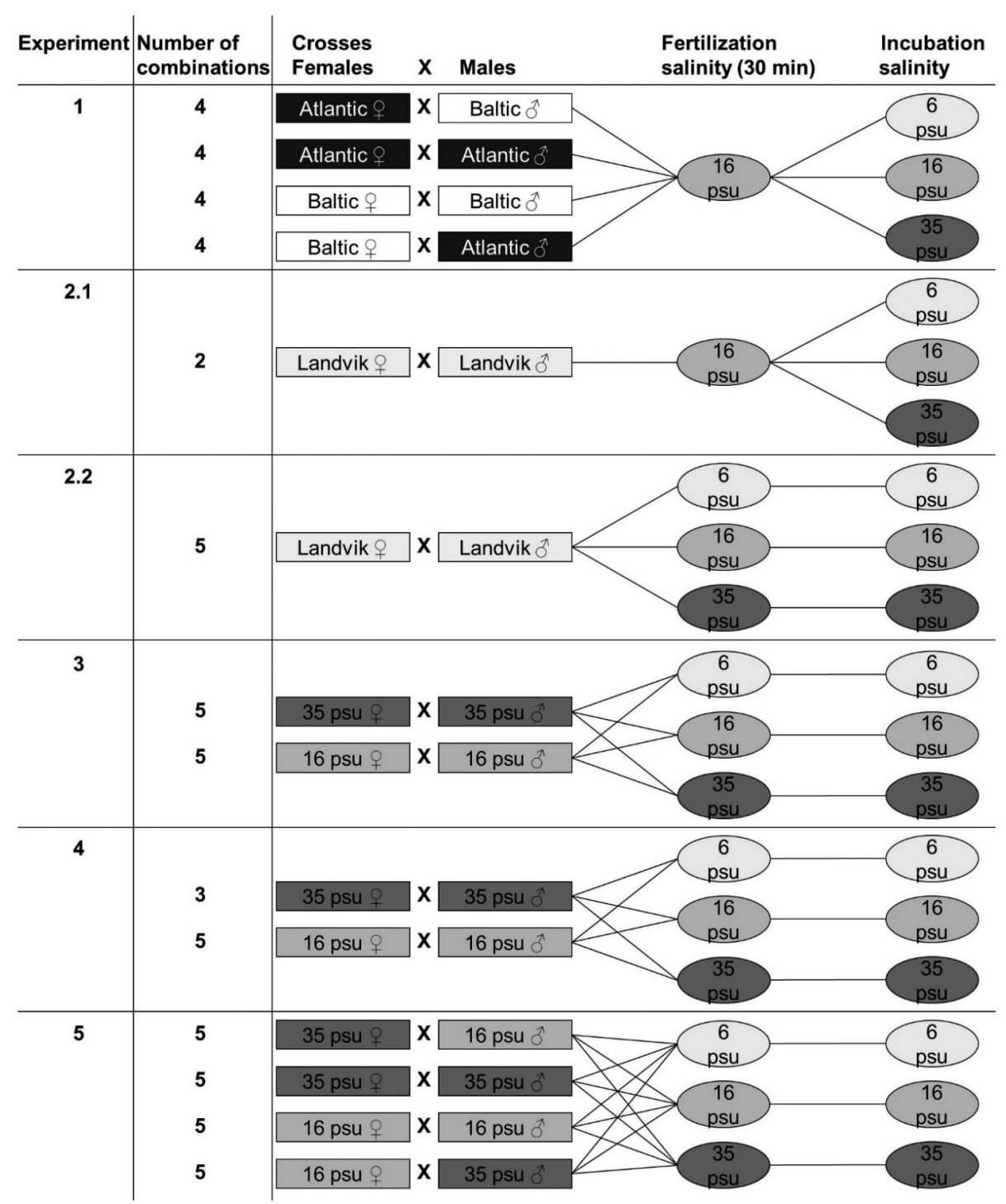

Fig. 1. Illustration of the experimental design used for the 5 different factorial crossing experiments. For Expts 1 and 5 , the same female and male herring were used for the within-group and between-group crosses. Parental herring used in Expts 1 and 2 were sampled from wild populations. Herring used in Expts 3 to 5 were F1 offspring from Expt 1 and had been reared their entire life in either 35 or 16 psu under common garden conditions (all fish reared communally to eliminate random environmental effects)

conducted at $16 \mathrm{psu}$. These are nominal values of the salinity because the actual values during incubation fluctuated between $5-7,15-17$, and 34-35 psu, respectively. The fertilization procedure was conducted in the respective salinities according to the following standard protocol: mature hydrated eggs were stripspawned on to 1 glass plate $(100 \times 150 \mathrm{~mm}$, Expt 1$), 2$ glass plates (Expt 2), 3 glass plates (Expts 3 and 4) or microscope slides $(25 \times 75 \mathrm{~mm}$, Expt 5) lying in individual plastic trays with water of designated salinity. Hereafter, all slides are referred to as plates. To obtain sperm, milt was collected in separate beakers by stripping male herring. By adding water of respective salinity, sperm were activated (Coward et al. 2002). The sperm solution of respective salinity was poured into the plastic trays containing plates with newly stripped adhesive eggs within 5 min after activation. After $30 \mathrm{~min}$, the opaque sperm-containing water covering the egg plates was flushed off with running water, and the plates were transferred into flowthrough incubation trays provided with water of given salinity. Ambient water temperatures were $\sim 9^{\circ} \mathrm{C}$ during incubation (Table $\mathrm{S} 1$ in the Supplement at www.int-res.com/articles/suppl/m617p081_supp.pdf). Light intensities fluctuated according to the seasonal and daily cycle in Bergen $\left(60^{\circ} \mathrm{N}\right)$. 


\subsection{Population samples}

For the first experiment (Fig. 1), spring-spawning herring caught on 21 May 2013 in the Atlantic, $\sim 12 \mathrm{~km}$ west of Bergen, Norway $\left(60^{\circ} 34^{\prime} 11.2^{\prime \prime} \mathrm{N}\right.$, $5^{\circ} 0^{\prime} 18.9^{\prime \prime} \mathrm{E}$ ), and in the Baltic, $\sim 80 \mathrm{~km}$ north of Uppsala, Sweden (60³8'52.0" N, $\left.17^{\circ} 48^{\prime} 44.2^{\prime \prime} \mathrm{E}\right)$, were used. These herring represent populations from marine (30-35 psu, Atlantic) and low salinity environments (6 psu, Baltic Sea). Herring were caught by gillnets during the night. The sample from the Baltic was collected before midnight (net set time $21: 00 \mathrm{~h}$, retrieval time 22:30 h), while the Atlantic samples were collected the next morning (net set time 20:00 h, retrieval time 08:00 h). Still-alive herring were terminally anesthetized, stored in individual plastic bags, and transported on ice (without direct contact) in a cooling box. Baltic herring were transported by airplane to Bergen. The experiment was conducted approximately $12 \mathrm{~h}$ and $2 \mathrm{~h}$ for herring from the Baltic and Atlantic, respectively, after retrieval of gillnets resulting in a total post mortem duration of ripe herring prior to experimentation of 12-14 h for Baltic herring and $2 \mathrm{~h}$ for Atlantic herring. In total, 4 combinations were fully reciprocally fertilized between and within both populations. The sperm activation and fertilization were conducted at $16 \mathrm{psu}$, and the egg plates were first transferred into the 3 respective salinities after $30 \mathrm{~min}$ for further incubation. One of these first filial (F1) generation combinations (1 Atlantic females vs. 1 Atlantic or Baltic male, respectively) was used to generate the Atlantic purebreds and Atlantic/Baltic hybrids used as parental fish to produce F2 offspring within Expts 3-5. By using only 1 female as parental female for Atlantic purebreds and Atlantic/Baltic hybrids, nonenvironmental maternal effects were purposely and effectively minimized.

For the second experiment (Fig. 1), the brackishwater population spawning in Landvikvannet at the Norwegian Skagerrak coast (58¹9'47.1"N, $\left.8^{\circ} 30^{\prime} 51.1^{\prime \prime} \mathrm{E}\right)$ were caught on 19 May 2015 where salinities were estimated to be 16 psu (Eggers et al. 2014). Herring were caught overnight with gillnets and collected the next morning (net set time 22:00 h, retrieval time 06:00 h). Still-alive herring were terminally anesthetized, stored in individual plastic bags, and transported on ice in a cooling box by airplane to Bergen. The crossing experiment was conducted $4 \mathrm{~h}$ post mortem of the ripe herring. Two combinations were fertilized at $16 \mathrm{psu}$ and transferred into respective salinities after $30 \mathrm{~min}$, while 5 combinations were directly fertilized at either 6,16 , or 35 psu.
The last 3 experiments (Expts 3-5) were conducted in spring 2016. Resulting Atlantic purebred and Atlantic/Baltic hybrid F1-offspring from one combination used in Expt 1 had been co-reared in the 3 respective incubation salinities (Berg et al. 2018). Purebreds and hybrids were initially co-reared at 3 salinities $(6,16$, and $35 \mathrm{psu})$ with 2 replicates $(1 \mathrm{~m}$ circular tanks) per salinity. Each tank included in total 1000 larvae at an initial ratio of 1:2 (purebred/ hybrid). For each tank, exactly 334 individual purebred larvae and 666 hybrid larvae were counted and added. The survival of herring larvae at 6 psu was low, and the component was terminated after 4 mo. Therefore, only herring juveniles from the replicates at 16 and 35 psu ( $\mathrm{n}=381$ and $\mathrm{n}=1158$, respectively) were combined in two $3 \mathrm{~m}$ circular tanks (1 tank per salinity) after $4 \mathrm{mo}$ and reared until maturity $3 \mathrm{yr}$ later. Weekly samples were collected during the larval stage and irregularly after merging of the juveniles (Fig. 2). The genetic analysis to discriminate purebred and hybrid larvae (prior to day 200) is in preparation. After 3 yr (when herring became mature), 282 and 918 herring remained at 16 and 35 psu, respectively. Water temperatures varied seasonally with an average of $9.1 \pm 0.7^{\circ} \mathrm{C}$ and $9.0 \pm 0.7^{\circ} \mathrm{C}$ at 16 and $35 \mathrm{psu}$, respectively (see Fig. S1 in the Supplement).

Expts 3 to 5 were conducted on the 1 st ( 7 June 2016), 2nd (15 June 2016), and 4th (29 June 2016) week of observed maturity (Table 1), following the

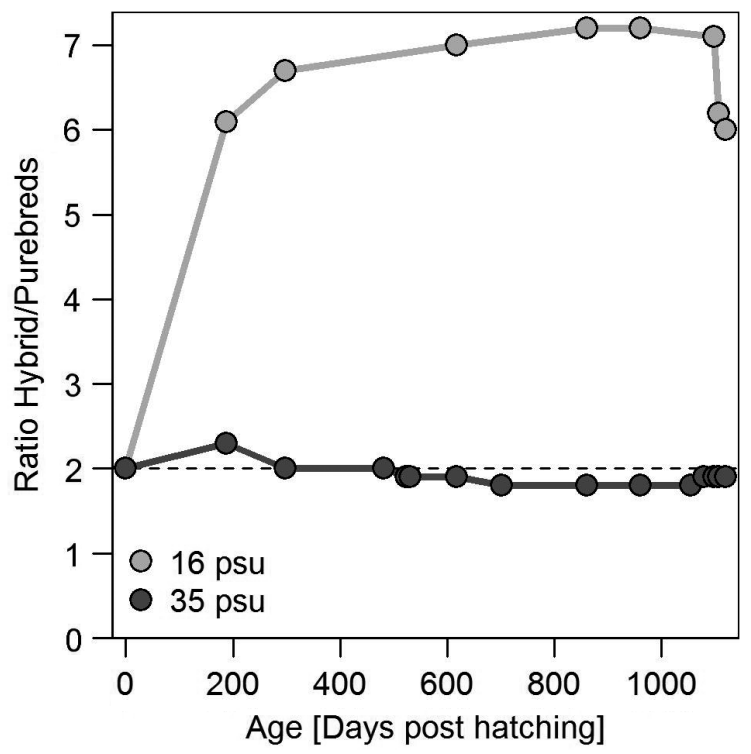

Fig. 2. Cumulative Hybrid/Purebred ratio for F1 herring reared under common garden conditions their entire life at 2 different salinities, 16 psu (light) and 35 psu (dark). Initial ratio was 2:1 for both salinities starting with 2000 larvae per salinity. Total numbers can be found in Table S2 in the Supplement 
Table 1. Post-mortem determination of genetic origin (hybrid vs. purebred) indicating total numbers of combinations used in Expts 3 to 5 split by genetics and salinity origin of the F1 generation. '-' indicates that combinations were not possible based on the experimental design (Fig. 1)

\begin{tabular}{|c|c|c|c|c|c|c|}
\hline \multirow[t]{2}{*}{ Experiment } & \multirow[t]{2}{*}{ Genetics } & \multirow[t]{2}{*}{ Salinity } & \multicolumn{2}{|c|}{ Hybrid male } & \multicolumn{2}{|c|}{ Purebred male } \\
\hline & & & $16 \mathrm{psu}$ & $35 \mathrm{psu}$ & $16 \mathrm{psu}$ & $35 \mathrm{psu}$ \\
\hline \multirow[t]{5}{*}{3} & 1st week of maturity $(7 / 6 / 2016)$ & & & & & \\
\hline & Hybrid female & $16 \mathrm{psu}$ & 5 & - & 0 & - \\
\hline & & $35 \mathrm{psu}$ & - & 3 & - & 2 \\
\hline & Purebred female & $16 \mathrm{psu}$ & 0 & - & 0 & - \\
\hline & & $35 \mathrm{psu}$ & - & 0 & - & 0 \\
\hline \multirow[t]{5}{*}{4} & 2nd week of maturity $(15 / 6 / 2016)$ & & & & & \\
\hline & Hybrid female & $16 \mathrm{psu}$ & 4 & - & 1 & - \\
\hline & & $35 \mathrm{psu}$ & - & 1 & - & 1 \\
\hline & Purebred female & 16 psu & 0 & - & 0 & - \\
\hline & & $35 \mathrm{psu}$ & - & 1 & - & 0 \\
\hline \multirow[t]{5}{*}{$5^{\mathrm{b}}$} & 4th week of maturity $(29 / 6 / 2016)$ & & & & & \\
\hline & Hybrid female & $16 \mathrm{psu}$ & $5^{\mathrm{a}}$ & 1 & 0 & $4^{\mathrm{a}}$ \\
\hline & & $35 \mathrm{psu}$ & 1 & 0 & 0 & 1 \\
\hline & Purebred female & $16 \mathrm{psu}$ & 0 & 0 & 0 & 0 \\
\hline & & $35 \mathrm{psu}$ & 4 & 2 & 0 & 2 \\
\hline \multirow[t]{5}{*}{$3-5$} & Total combinations used (all weeks) & & & & & \\
\hline & Hybrid female & $16 \mathrm{psu}$ & 13 & 1 & 1 & 3 \\
\hline & & $35 \mathrm{psu}$ & 1 & 4 & 0 & 4 \\
\hline & Purebred female & $16 \mathrm{psu}$ & 0 & 0 & 0 & 0 \\
\hline & & $35 \mathrm{psu}$ & 4 & 3 & 0 & 2 \\
\hline
\end{tabular}

standard protocol. F1 herring were collected inhouse and terminally anesthetized $1 \mathrm{~h}$ prior the start of the experiment. Due to the co-rearing in one tank, herring could initially only be distinguished based on their salinity origin (16 vs. $35 \mathrm{psu}$ ). The determination of genetic origin (hybrid vs. purebred) was conducted post-mortem and after the fertilization (explained below; Table 1). For the third and fourth experiment (Fig. 1), only herring from the same salinity were crossed. During Expt 3, 5 combinations from each salinity group were used. During the fourth experiment, 6 and 3 combinations were used from salinity groups originating from 16 and 35 psu, respectively. For the fifth experiment (Fig. 1), 5 combinations consisting of crosses from each salinity group were fertilized between and within both groups in a fully reciprocal design. During this experiment, 1 female originating from 16 psu was overripe yielding poor subsequent survival of eggs and was thus removed from the analysis (see Table S4).

\subsection{Life-history trait measurements}

In total, 414 plates were used for the 5 experiments at 3 different salinities to evaluate 3 life history traits:
(1) fertilization rate, (2) egg size, and (3) hatching rate. Digital pictures of a randomly chosen section of each plate were taken $24 \mathrm{~h}$ after fertilization. The section area of $\sim 1 \mathrm{~cm}^{2}$ was determined by the resolution of the microscope magnification needed to identify whether eggs were fertilized or not. All eggs that could be clearly identified as fertilized or non-fertilized eggs were counted. Fertilization rates ( $f$ ) were estimated as follows:

$$
f=\frac{N_{f}}{N_{t}}
$$

where $N_{f}$ represents the number of fertilized eggs, and $N_{t}$ is the total number of eggs. $N_{t}$ ranged from 50 to 282 eggs $($ mean $=156)$ per photographed section. The same images were used to measure egg sizes (projected 2-D area, hereafter termed area) for all females used in the 5 experiments. For each plate, up to 20 fertilized and 20 unfertilized eggs were measured using ImageJ (v. 1.48). Only eggs that were not deformed by the proximity of other eggs were evaluated. Hatching rates $(H)$, only estimated for the fifth experiment, were estimated as follows:

$$
H=\frac{N_{L}}{N_{L}+N_{E}}
$$


where $N_{L}$ represents the total number of hatched larvae, and $N_{E}$ is the total number of developed but unhatched embryos on each plate.

\subsection{Genotype analysis of hybrids and purebreds}

Atlantic/Baltic hybrids and Atlantic purebreds were identified post-mortem by genotyping a diagnostic SNP using a Custom TaqMan ${ }^{\circledR}$ Assay Design Tool where the Baltic male was homozygous C (cytosine), while the Atlantic male and female were homozygous $\mathrm{T}$ (thymine) at a specific SNP locus (scaffold95_175856_SNP00029) (Berg et al. 2018).

\subsection{Statistical analysis}

All statistical analyses and plotting were conducted in the R software (R Core Team 2017). For all tests, we used 0.05 as the level of significance. For statistical analyses, we used linear mixed-effects models to indicate how fertilization rates, hatching rates, or egg sizes were influenced by salinity, genetic, or parental effects. The modelling followed a backward selection approach incorporating all fixed and random effects. Significant differences among several variables were identified using Tukey-HSD tests. The full starting model included the following variables and full interaction term between them:

$$
\begin{aligned}
Y= & \alpha+\beta_{1} \times \mathrm{Sal}+\beta_{2} \times F_{\mathrm{Gen}}+\beta_{3} \times M_{\mathrm{Gen}}+\beta_{4} \times F_{\text {Sal }} \\
& +\beta_{5} \times M_{\mathrm{Sal}}+\beta_{6} \times \text { Week }+\alpha+\varepsilon
\end{aligned}
$$

$Y$ represents the fertilization/hatching rate or egg size, $S a l$ the fertilization salinity, $F_{\mathrm{Gen}}$ and $M_{\mathrm{Gen}}$ the genetic origin, and $F_{\text {Sal }}$ and $M_{\text {Sal }}$ the rearing salinity of the female or male, respectively. Week is the week of maturity when available. The term $a$ is the random intercept for the individual experiment/combination/salinity/plate. The structure was adjusted for each model. Unfertilized and fertilized eggs were analysed separately. The optimal structure of the random effects was tested using a likelihood ratio test based on the models fitted by restricted maximum likelihood estimations (REML) (Zuur et al. 2009). Further, based on REML fits, the fixed effects structure was optimized using marginal $F$-statistics (Pinheiro \& Bates 2000). For all models, both the random effect $a$ and the residual $\varepsilon$ were assumed to be normally distributed with mean of zero and variance $\sigma_{\text {pop }}^{2}$. All mixed-effects models were fitted using the 'Ime' function within the 'nlme' R-package (Pinheiro \& Bates 2000).

\section{RESULTS}

\subsection{Rearing of hybrids and purebreds}

Within the first $200 \mathrm{~d}$ after hatching (DPH), the survival of hybrids in 16 psu greatly exceeded that of purebreds (binomial test, $\mathrm{p}<0.001$; Fig. 2). The initial starting ratio of $2: 1$ increased to $\sim 6: 1$, a ratio that remained relatively stable until first maturity after nearly 3 yr. No selection was evident at 35 psu, and the ratio was not different from the initial 1:2 ratio (binomial test, $\mathrm{p}>0.05$ ).

In general, the frequency distribution of maturity stages during the spawning period indicated that purebreds matured later than hybrids (KolmogorovSmirnov tests, $\mathrm{p}<0.05$; Fig. 3). There were no differences in terms of maturity development between hybrids originating from either 16 or 35 psu (Kolmogorov-Smirnov tests, $p>0.05$ ). Purebreds originating from 16 psu seemed to stop developing before they reached maturity. This resulted in only one purebred from 16 psu in spawning conditions (a male) being used within this study (Table 1).

\subsection{Fertilization rates of wild populations (Expts 1 and 2)}

Only the male genetic origin affected the fertilization rates of wild Atlantic and Baltic herring (ANOVA, $\mathrm{df}=1, F=8.6, \mathrm{p}<0.01)$. Atlantic males had a higher fertilization rate than Baltic males (Fig. 4). In general, the fertilization rates were lower $(<60 \%)$ using wild fish (Expts 1 and 2) compared to herring reared in the laboratory (Expts 3-5; Figs. 4 \& 5). The salinity to which the eggs were transferred 30 min after mixing of gametes had no influence on the observed fertilization rates (ANOVA, $\mathrm{df}=2, F=0.06, \mathrm{p}>0.05$ ).

Similarly, no differences among incubation salinities were observed for the 2 combinations of the Landvik population, initially fertilized at 16 psu and then transferred into respective salinities $30 \mathrm{~min}$ after mixing of gametes. The fertilization rates of these 2 combinations were higher $(>80 \%$; Fig. 4), however, than those fertilized at the respective salinities. For Landvik combinations where the fertilization was conducted directly in the respective salinity, fertilization rates were highest $(\sim 60 \%)$ and lowest $(\sim 10 \%)$ at 16 and 6 psu, respectively (ANOVA, df $=2, F=5.1, \mathrm{p}<0.05$ ). Fertilization rates at 35 psu were variable. While 3 combinations had low fertilization rate $(\sim 10 \%), 2$ combinations had higher fertilization success at $35 \mathrm{psu}$ (>50\%) than at $16 \mathrm{psu}$ (Table S3 in the Supplement). 


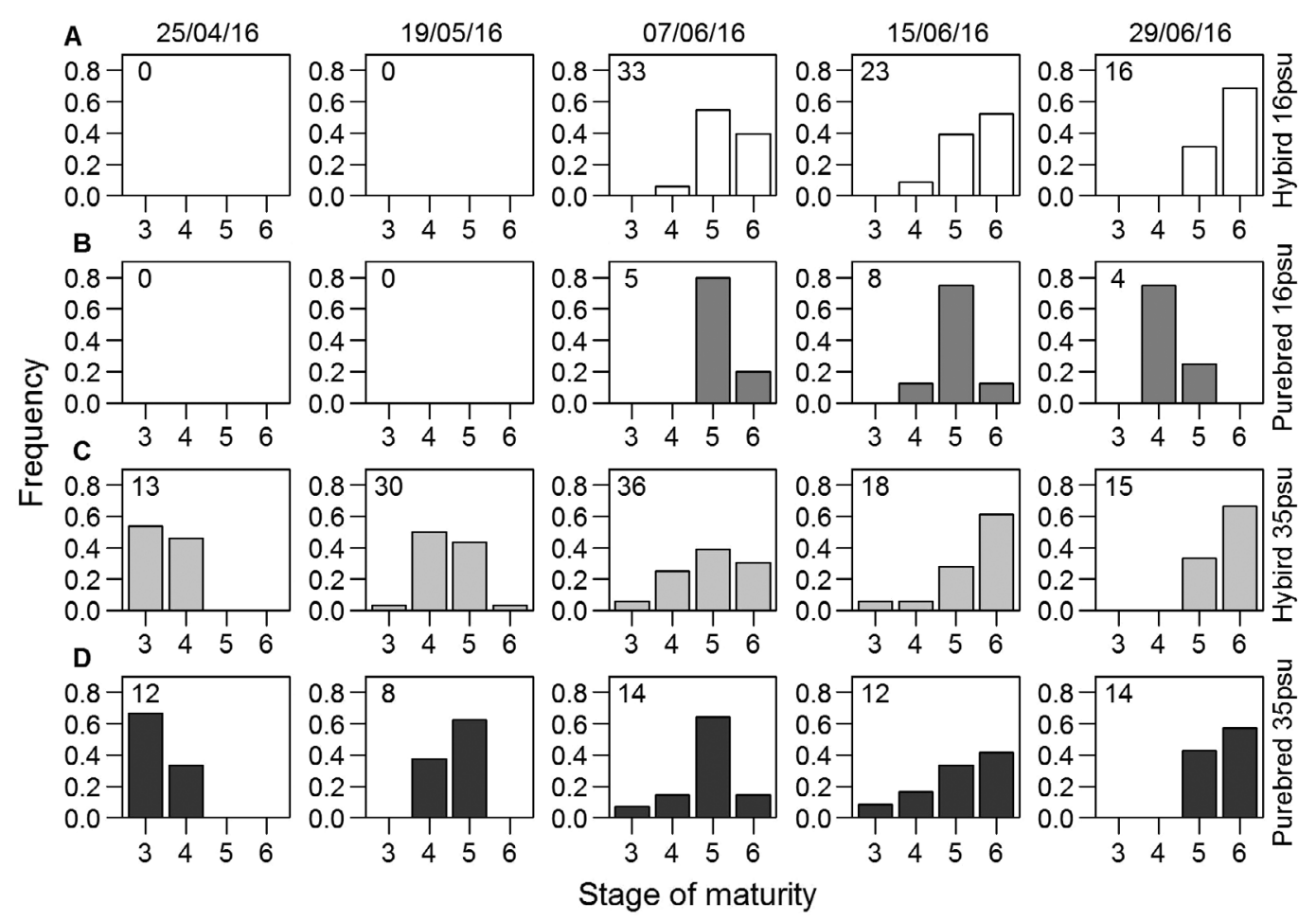

Fig. 3. Development of maturity estimated by stages over the spawning season of $\mathrm{F} 1$ herring reared under common garden conditions for (A) Atlantic/Baltic hybrids and (B) Atlantic purebreds originating from 16 psu, and (C) Atlantic/Baltic hybrids and (D) Atlantic purebreds originating from 35 psu. Stage of maturity 6 indicates spawning and ripe condition of herring;

Stages 3 to 5 are pre-spawning conditions (Mjanger et al. 2017). The total number of herring is in the upper left corner

\subsection{Fertilization rates of $F 1$ herring reared under common garden conditions (Expts 3-5)}

For a general overview, first, only fertilization rates of combinations with males and females from the same salinity and hybrid females were compared. Fertilization rates of these combinations were dependent on salinity during fertilization (ANOVA, $\mathrm{df}=$ $2, F=81.4, \mathrm{p}<0.001)$, the parental salinity condition (ANOVA, df =1, F=1106.5, $\mathrm{p}<0.001$ ), and male ge-

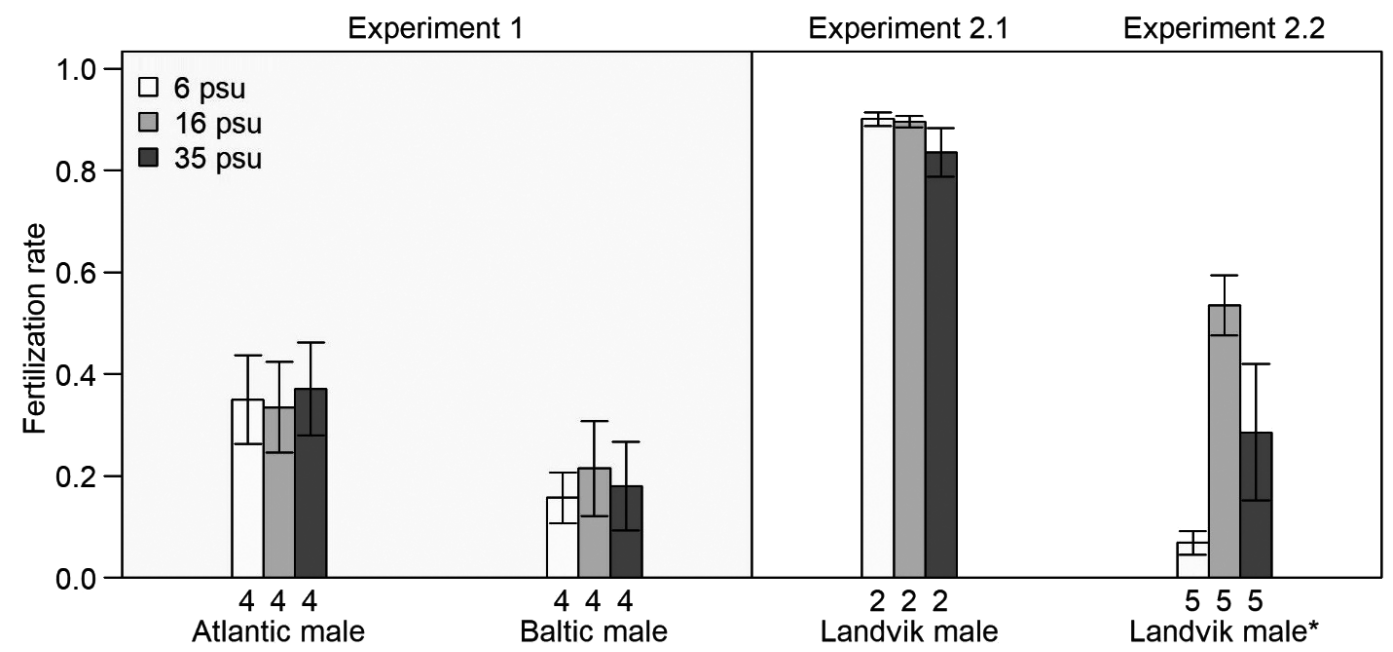

Fig. 4. Mean fertilization rates of Expts 1 and 2 separated by male genetic origin. Fertilization was conducted at 16 psu, and the egg plates were transferred into 3 different incubation salinities $(6,16$ and 35 psu) after 30 min. Error bars = standard error, and the total number of herring in the respective crosses are given under the bars. Each Atlantic and Baltic male was used

twice to cross with 1 Atlantic and with 1 Baltic female. ${ }^{*}$ Fertilization was conducted directly at the 3 different salinities 
netic origin (ANOVA, $\mathrm{df}=1, F=5.9, \mathrm{p}<0.05$ ) as well as their interaction with the week of maturity. Fertilization rates were overall $>75 \%$, except for males originating from 16 psu when fertilization was conducted at 35 psu (Fig. 5). In these cases, fertilization rates were generally $<10 \%$. Highest fertilization rates were observed at $16 \mathrm{psu}$ for all combinations (Tukey HSD test, $\mathrm{p}<0.001$ ). There was also a significant decrease of fertilization rates in the 4 th week of maturity at all 3 salinities, but most prominent at 6 psu (Fig. 5).

During Expt 5, the fertilization rates of full reciprocal combinations were affected by salinity during fertilization (ANOVA, df $=2, F=22.3, \mathrm{p}<0.001$ ), male salinity (ANOVA, df $=1, F=119.6, \mathrm{p}<0.001$ ), and male genetic origin (ANOVA, df $=1, F=60.1, \mathrm{p}<$ 0.001). Again, fertilization rates at 16 psu were highest overall (>70\%) for all combinations (Fig. 6). Purebred males had higher fertilization rates than hybrid males at $35 \mathrm{psu}$, when originating from $35 \mathrm{psu}$ (Tukey HSD tests, $\mathrm{p}<0.001$ ). Hybrid males originating from $16 \mathrm{psu}$ had higher fertilization rates at $6 \mathrm{psu}$, but lower rates at $35 \mathrm{psu}$ compared with hybrids from 35 psu (Tukey HSD tests, $\mathrm{p}<0.001$ ). In addition, malformed and fertilized eggs that stopped developing were observed only in the 4 th week of maturity for all females. The fertilization rates at 16 psu of each individual female used in Expt 5 were similar regardless of male salinity origin (individual ANOVAs per female: $\mathrm{p}>0.05$; Table S4 in the Supplement).

\subsection{Egg size and hatching rates}

Fertilized eggs were larger than unfertilized eggs (ANOVA, df =1, F= 24007.5, p < 0.001; Fig. 7); therefore, the analyses were conducted separately for fertilized and unfertilized eggs. Among the Atlantic females, 2 distinct clusters were identified (Tukey HSD tests on individual females, $\mathrm{p}<0.001$ ) having different egg sizes without any overlap (Table S5 in the Supplement). The single founder female producing both the hybrids and purebreds had eggs belonging to the cluster with smaller egg sizes. For a general comparison, females having larger eggs were excluded from the analysis to avoid violating the assumption of normality and homogeneity of variance. Egg sizes were different among females from all 5 groups (Atlantic, Baltic, Landvik, purebreds, and hybrids; ANOVA unfertilized eggs, $\mathrm{df}=4, F=87.1, \mathrm{p}<$ 0.001; ANOVA fertilized eggs, df $=4, F=71.7, \mathrm{p}<$

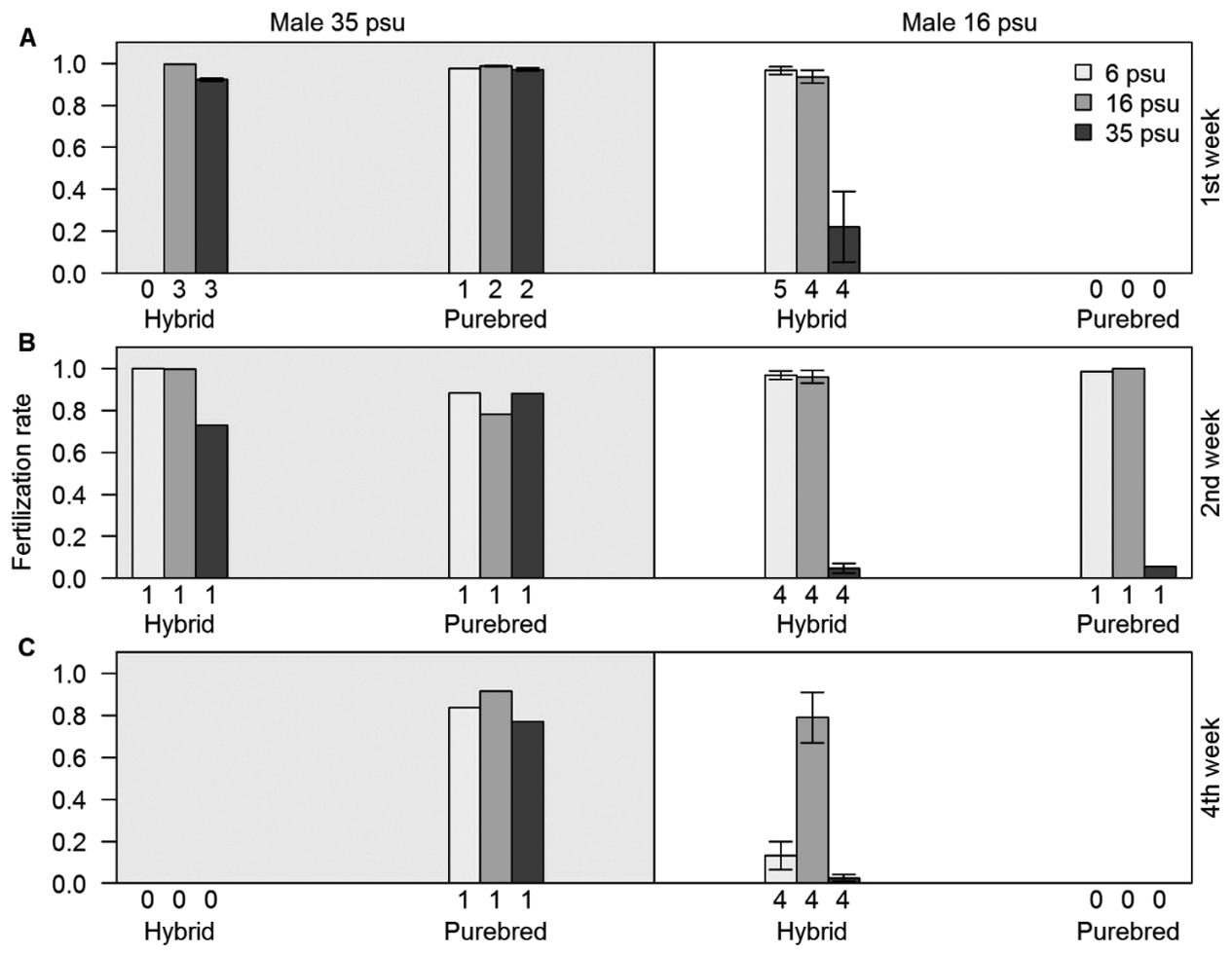

Fig. 5. Mean fertilization rates of Atlantic/Baltic hybrids and Atlantic purebreds at 3 salinities (6, 16 and 35 psu) during the (A) 1st week, (B) 2nd week, and (C) 4th week of maturation separated by male salinity and genetic origin. Only fertilization rates of combinations consisting of males and females from the same salinity and hybrid females are presented. The standard error and total number of herring used in the respective crosses are displayed 


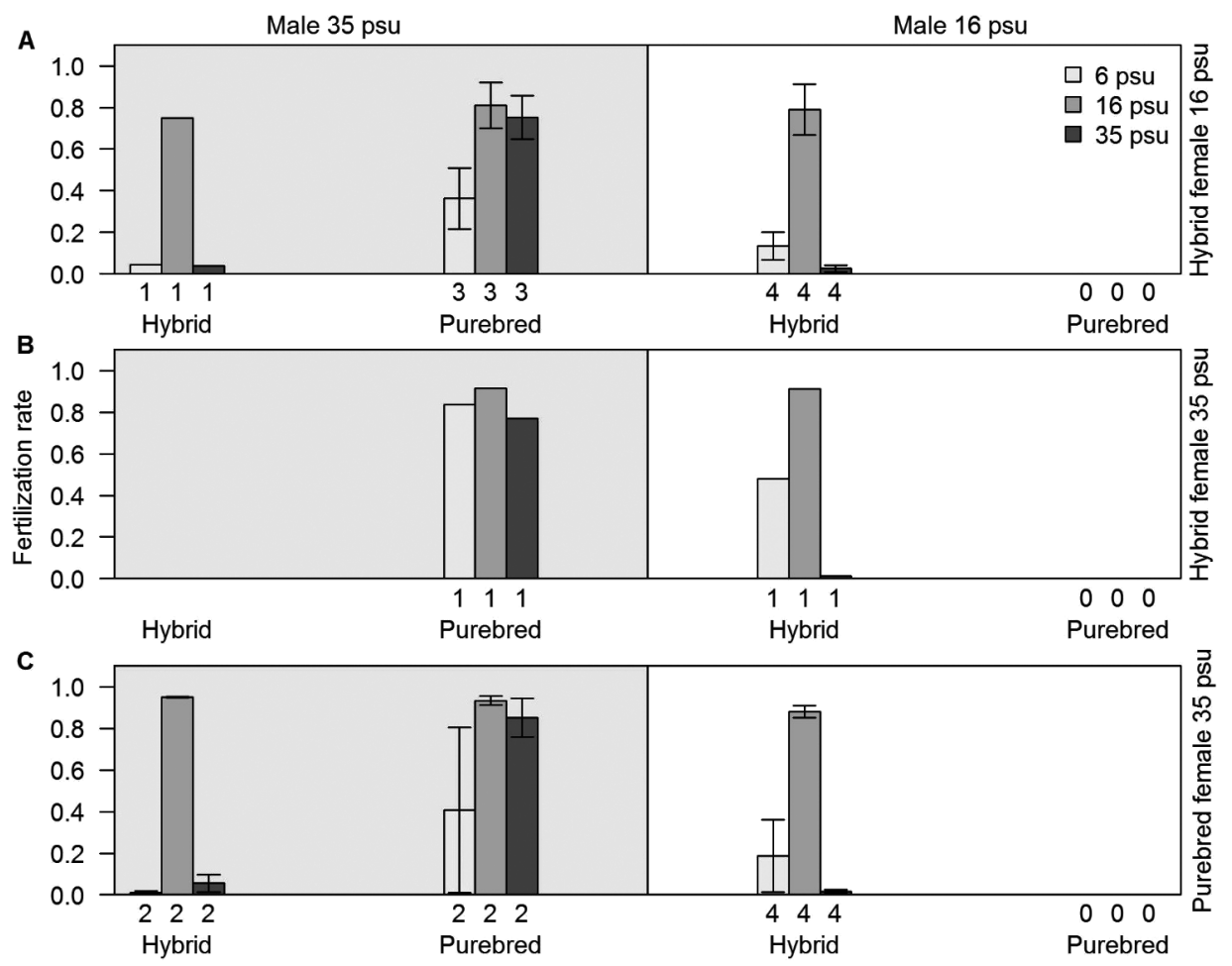

Fig. 6. Mean fertilization rates of Atlantic/Baltic hybrids and Atlantic purebreds at 3 salinities (6, 16 and 35 psu) in Expt 5 for hybrid females originating from (A) 16 psu and (B) 35 psu, as well as (C) purebred females originating from 35 psu. Fertilization rates are separated by male salinity and genetic origin. The standard error and total number of herring used in the respective crosses are displayed

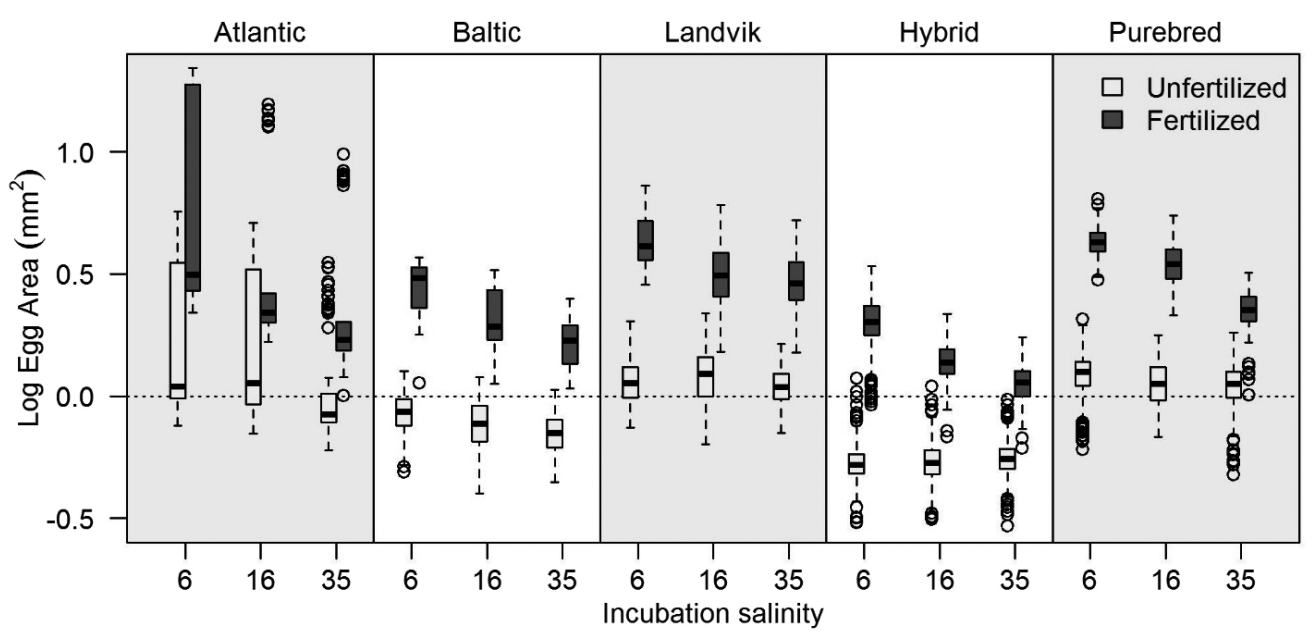

Fig. 7. Egg sizes of females at 3 salinities $(6,16$ and 35 psu) from 3 wild populations (Atlantic, Baltic [both Expt 1], Landvik [Expt 2]) and 2 genetic groups (Hybrids and purebreds [both combined for Expts 3 to 5]), which were reared under common garden conditions. The median is indicated in the boxes, which represent the interquartile range. Whiskers represent the lowest and highest observations within 1.5× the interquartile range. Observations outside the whiskers are outliers indicated as individual points. Boxes for unfertilized eggs are offset to the left for visual clarity. Note that the Atlantic herring group consisted of 2 size clusters of egg sizes. See Tables S5 to S10 in the Supplement for the raw data

0.001; Fig. 7). Within each group, fertilized egg sizes decreased as the salinity increased from 6 to $35 \mathrm{psu}$ (ANOVA fertilized eggs, $\mathrm{df}=2, F=580.4, \mathrm{p}<0.001$ ). There was a significant interaction between female genetics and salinity for unfertilized eggs (ANOVA unfertilized eggs, $\mathrm{df}=8, F=3.1, \mathrm{p}<0.01$ ), but without any clear trend. Atlantic females had the largest eggs, even though females of the larger cluster were excluded. Females of Landvik and purebred females had similar egg sizes. Baltic eggs were smaller, and 


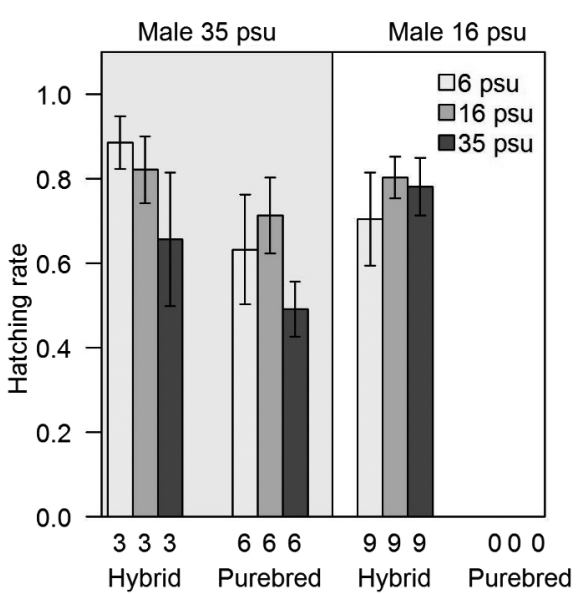

Fig. 8. Hatching rates at 3 salinities $(6,16$ and $35 \mathrm{psu})$ of offspring from F1 Atlantic/Baltic hybrids and Atlantic purebreds produced during Expt 5 separated by male salinity and genetic origin. The standard error and total number of herring for the respective crosses are given

hybrids had the smallest eggs, both fertilized and unfertilized (Tukey HSD tests, $\mathrm{p}<0.001$ ). The size of fertilized eggs was clearly correlated to the size of unfertilized eggs (ANOVA: $\mathrm{df}=1, F=1072.4, \mathrm{p}<0.01, \mathrm{r}^{2}=$ 91.8; Fig. S2 in the Supplement) and the incubation salinity (ANOVA: $\mathrm{df}=2, F=34.4, \mathrm{p}<0.01$ ). The size increase from unfertilized to fertilized eggs was approximately 1.7-, 1.9-, and 2.1-fold for 6, 16, and 35 psu, respectively, and not affected by the genetic origin of females. Of those Landvik females fertilized directly in the respective salinities, 2 females, which also had high fertilization rates at $35 \mathrm{psu}$ (Table S3), had larger eggs (Tukey HSD tests, $\mathrm{p}<0.05$; Table S5). Within the other groups (Baltic, purebreds, and hybrids), egg sizes of individual females were comparable (typically $<6 \%$ difference in means, Tukey HSD tests, $\mathrm{p}<0.05$; Tables S5 to S7 in the Supplement) and combined for purebreds and hybrids used in Expts 3-5. F2 offspring of F1 hybrids and purebreds had $>50 \%$ hatching rates (Fig. 8). Hatching rates were not influenced by the genetics of the parents, fertilization salinity, or parental origin salinity (ANOVA: $p>0.05$ ).

\section{DISCUSSION}

To our knowledge, this is the first study where viable offspring of herring have been reared in captivity until sexual maturity and then used to produce a second generation of laboratory-reared herring. Our study confirmed that Atlantic herring Clupea harengus can reproduce viable offspring at salinities from 6 to $35 \mathrm{psu}$. We also confirm that herring origi- nating from regions with very different salinities are interfertile. However, the reproductive success of laboratory crosses was dependent on the origin of herring both in terms of genetics and salinity. The salinity at which the reproduction occurred had only a minor impact. The exception was for male herring originating and reared at low salinity (16 psu): subsequent reproductive success decreased at high salinity (35 psu). Seasonal timing also plays an important role. Herring appeared to be less tolerant to a highor low-salinity environment after they had passed their optimal spawning condition. Despite varying fertilization rates, most eggs hatched when fertilization was successful. In addition to the differences in reproductive success, the populations we examined had divergent strategies in reproductive investment indicated by variation in egg sizes.

Herring were capable of reproducing not only in their native salinity but also in salinities markedly deviating from their ambient conditions. Atlantic herring are more tolerant to high salinity at fertilization than Pacific herring Clupea pallasii (Alderdice et al. 1979). Surprisingly, our results suggested an improved reproductive success under intermediate brackish water conditions for all populations even though this was not their native salinity. Reproductive success in brackish water probably fostered the recent colonization of Landvikvannet, a former freshwater lake now a brackish water system resembling a miniature Baltic Sea with a salinity of $\sim 18$ psu in the sub-surface oxygenated parts of the water column (Eggers et al. 2014). Other marine species also have optimal fertilization rates in salinities at approximately 16 to 20 psu (Billard 1978, Griffin et al. 1998). Intermediate salinity also can be optimal for the growth and food conversion during early life stages (Bœuf \& Payan 2001, Imsland et al. 2001).

Similar fertilization rates of combinations initially fertilized in the same salinity but incubated across salinities indicate that the critical period determining fertilization success is the first minutes after the eggs and sperm are released into the water. Even though herring sperm can remain fertile for $>24 \mathrm{~h}$ (Yanagimachi et al. 1992), the actual fertilization may occur even within the first seconds and is dependent on the sperm density (Rosenthal et al. 1988). This suggests that the influence of salinity on the fertility/survival of the eggs or sperm appears relatively early after their release. Osmotic stress on sperm is much higher due to a larger surface/volume ratio for sperm compared to unfertilized eggs (Holliday \& Blaxter 1960), potentially resulting in lowered fertilization rates. Thus, the fertilization rates may depend more on 
paternal characteristics. In addition, the osmotic pressure may also affect the closure of micropyles of unfertilized eggs (Iwamatsu et al. 1993). However, the osmotic pressure in eggs increases markedly after fertilization. The increasing size of fertilized eggs in the lower salinities can thus be explained by an increase in water influx in eggs not yet capable of functional osmoregulation (Holliday \& Blaxter 1960).

The full reciprocal cross between Atlantic (35 psu) and Baltic (6 psu) herring demonstrated that gene flow among populations from spawning grounds with different environmental conditions can theoretically occur. Due to the study design, a detailed comparison of the fertilization rates was not possible for Atlantic and Baltic herring because all initial fertilizations were conducted at $16 \mathrm{psu}$. Still, fertilization rates of their offspring clearly demonstrated the adaptation of Baltic herring to low salinity conditions. The adaptation to low-salinity conditions was even clearer at $35 \mathrm{psu}$, where fertilization rates of hybrids originating from 16 psu were very low $(<20 \%)$. This is consistent with a recent study of Poirier et al. (2017), which also suggested that local adaptation to low salinity depends on the paternal origin. In contrast to their results, however, the hatching rates in our study were not influenced by any paternal or maternal origin or environmental conditions. Further, males influence not only the reproductive success, as demonstrated in this study, but also the early life dynamics, e.g. larval length or yolk-sac volume, of herring (Bang et al. 2006).

Baltic herring are highly adapted to their environmental conditions (Rajasilta et al. 2011), and genetic polymorphism in the fish hatching enzyme in herring may be linked to hatching salinity (Martinez Barrio et al. 2016). This heritable adaptation of the parental Baltic population to low salinity is indicated by a higher mortality of purebred larvae from the F1 generation reared at 16 psu (Fig. 2). In addition, purebreds stopped their maturity development before they reached spawning condition at $16 \mathrm{psu}$. Our results of differential survival according to origins show signs of adaptation to low-salinity conditions after only one generation living in a stable environment. Such adaptations and ecological selection can result in rapid speciation (Erlandsson et al. 2017, Momigliano et al. 2017). Further, stable environments, as provided by common garden conditions, are necessary to indicate adaptation, while fluctuating environments may rather result in phenotypic plasticity (Lande 2009).

In addition to the ecological and physiological aspects influencing the reproductive success, the timing of spawning is of high importance. The lower fertilization rates in the 4 th week of maturity might be an impact of holding females too long after they reach the prime of sexual readiness (Hay 1986). The stage of maturity (not fully mature or overripe) of females and sometimes males may also negatively impact the fertilization results of experiments using wild populations (see for example Table S3). Likewise, the handling time of wild herring from capture to actual fertilization could be a potential source of experimental error, even though it has been shown that fertilization experiments can be successfully conducted up to $20 \mathrm{~h}$ after capture (Blaxter 1955, Blaxter \& Hempel 1961). Experiencing the longest handling time ( 12-14 h), Baltic females had slightly lower fertilization rates than Atlantic females $(\sim 2-4 \mathrm{~h}$ handling time; Table S3). The Baltic males yielded general lower reproductive success than Atlantic males, which could be a consequence of the longer handling time. However, Landvik herring yielded relatively high reproductive success (Expt 2.1) compared to Atlantic and Baltic herring despite their handling time ( 4-6 h). The highest fertilization rates were observed for herring collected in-house and terminally anesthetized $1 \mathrm{~h}$ before the experiment. However, even if the handling time influenced the overall fertilization rates of herring samples, a systematic bias with respect to salinity at fertilization is not anticipated in the different experiments.

After spawning, the osmotic pressure has a major influence on the size of fertilized eggs. The size (area) of fertilized eggs decreased by $\sim 0.1 \mathrm{~mm}^{2}$ with an increasing salinity of $10 \mathrm{psu}$, in accordance with other studies (Holliday \& Blaxter 1960). These changes in egg size as well as the approximate 1.8-fold increase in size from unfertilized to fertilized eggs was independent of the genetic origin. The effect of salinity osmotic gradients on the development of herring needs to be further investigated. However, the hatching rate in this study was not influenced by the fertilization salinity and a following change in egg size. It seems that herring embryos are relatively tolerant and unlikely to be affected by salinity changes (Holliday \& Blaxter 1960).

In general, larger herring eggs will result in larger larvae with a faster larval development (Blaxter \& Hempel 1963, Gamble et al. 1985), but smaller eggs indicate higher fecundity (dos Santos Schmidt et al. 2017). Atlantic purebreds had larger eggs than the wild Atlantic females used to produce the F1 offspring, while Atlantic/Baltic hybrids had smaller eggs. The fecundity of experimentally-reared herring may be higher than that of wild herring, since ample food is available and stress factors (like predation, overwintering, and spawning migrations) are 
reduced. Further, a mixture of herring can explain the 2 clusters within the parental Atlantic populations. Stationary and migratory herring have different egg sizes (Silva et al. 2013); therefore, the cluster with larger egg sizes may be similar to herring of the migratory Norwegian spring spawning herring. The second cluster may represent the traits of a more stationary and local population. This was supported by a genetic analysis which indicated that the Atlantic herring included in this study represented both oceanic Norwegian spring spawners and a coastal population (Lamichhaney et al. 2017).

Despite their extensive migrations, some herring populations have been documented to return to their natal spawning grounds (Ruzzante et al. 2006) to maximise larval retention on the spawning grounds at the early life history stages (Sinclair \& Power 2015). Within the Baltic Sea, decreasing salinities as a consequence of climate-driven changes (Meier et al. 2006, Vuorinen et al. 2015) or the loss of spawning substrate due to anthropogenic alterations of coastal spawning sites (Kanstinger et al. 2018) can force herring to alter their spawning grounds (Illing et al. 2016). Further, habitat degradation and the loss of structural complexity of spawning substrates can result in higher egg mortality (von Nordheim et al. 2017). However, the reduced fitness, as measured by lowered fertilization success of offspring spawned at different salinities compared to that previously inhabited by the parental fish, is expected to have evolutionary consequences when spawning fish have to colonize diverging salinity habitats or when interbreeding between populations from different salinity habitats might occur.

In conclusion, our study indicates the adaptation of different herring populations to their original environmental conditions in terms of salinity. Still, all populations yield some reproductive success in salinities ranging from 6 to 35 psu. Further, the adaptation to salinity conditions of parental fish is transmitted to their offspring within the next generation. Interbreeding of populations from diverging salinity habitats is possible.

Acknowledgements. We are grateful to Christel Krossøy, Frank Midtøy, Heikki Savolainen and Julie Skadal from the $\mathrm{UiB}$ and other technicians from ILAB for their efforts in the common garden experiments and rearing of herring over $>3 \mathrm{yr}$. We also acknowledge Julie T. Kvalheim for measuring the egg sizes in the last experiment. The 2 anonymous reviewers are thanked for their very valuable suggestions and constructive comments for improvements to the manuscript. We also thank Dorothy J. Dankel for a final proofreading. This work was funded by a grant from the Knut and Alice Wallenberg foundation to L.A. and the RCN project 254774 (GENSINC).

\section{LITERATURE CITED}

Alderdice DF, Rao TR, Rosenthal H (1979) Osmotic responses of eggs and larvae of the Pacific herring to salinity and cadmium. Helgol Mar Res 32:508-538

Andersen $\varnothing$, Wetten OF, De Rosa MC, Andre C and others (2009) Haemoglobin polymorphisms affect the oxygenbinding properties in Atlantic cod populations. Proc R Soc B 276:833-841

Andrén T, Björck S, Andrén E, Conley D, Zillén L, Anjar J (2011) The development of the Baltic Sea basin during the last $130 \mathrm{ka}$. In: Harff J, Björck S, Hoth P (eds) The Baltic Sea Basin. Springer, Berlin, Heidelberg

* Bang A, Grønkjær P, Clemmesen C, Høie H (2006) Parental effects on early life history traits of Atlantic herring ( $\mathrm{Clu}$ pea harengus L.) larvae. J Exp Mar Biol Ecol 334:51-63

*Bekkevold D, André C, Dahlgren TG, Clausen LAW and others (2005) Environmental correlates of population differentiation in Atlantic herring. Evolution 59:2656-2668

Bekkevold D, Clausen LAW, Mariani S, André C, Christensen TB, Mosegaard H (2007) Divergent origins of sympatric herring population components determined using genetic mixture analysis. Mar Ecol Prog Ser 337: 187-196

Berg F, Almeland OW, Skadal J, Slotte A, Andersson L, Folkvord A (2018) Genetic factors have a major effect on growth, number of vertebrae and otolith shape in Atlantic herring (Clupea harengus). PLOS ONE 13: e0190995

* Billard R (1978) Changes in structure and fertilizing ability of marine and preshwater fish spermatozoa diluted in media of various salinities. Aquaculture 14:187-198

Blaxter JHS (1955) Herring rearing - I. The storage of herring gametes. Mar Res Scot No. 3

Blaxter JHS, Hempel G (1961) Biologische Beobachtungen bei der Aufzucht von Heringsbrut. Helgol Mar Res 7: 260-283

* Blaxter JHS, Hempel G (1963) The influence of egg size on herring larvae (Clupea harengus L.). J Cons Int Explor Mer 28:211-240

B Bœuf G, Payan P (2001) How should salinity influence fish growth? Comp Biochem Physiol C Toxicol Pharmacol 130:411-423

Coward K, Bromage NR, Hibbitt O, Parrington J (2002) Gamete physiology, fertilization and egg activation in teleost fish. Rev Fish Biol Fish 12:33-58

dos Santos Schmidt TC, Slotte A, Kennedy J, Sundby S and others (2017) Oogenesis and reproductive investment of Atlantic herring are functions of not only present but long-ago environmental influences as well. Proc Natl Acad Sci USA 114:2634-2639

Eggers F, Slotte A, Libungan LA, Johannessen A and others (2014) Seasonal dynamics of Atlantic herring (Clupea harengus L.) populations spawning in the vicinity of marginal habitats. PLOS ONE 9:e111985

* Erlandsson J, Östman Ö, Florin AB, Pekcan-Hekim Z (2017) Spatial structure of body size of European flounder (Platichthys flesus L.) in the Baltic Sea. Fish Res 189:1-9

*Gamble JC, MacLachlan P, Seaton DD (1985) Comparative growth and development of autumn and spring spawned Atlantic herring larvae reared in large enclosed ecosystems. Mar Ecol Prog Ser 26:19-33

*Griffin FJ, Pillai MC, Vines CA, Kaaria J, Hibbard-Robbins T, Yanagimachi R, Cherr GN (1998) Effects of salinity 
on sperm motility, fertilization, and development in the Pacific herring, Clupea pallasi. Biol Bull 194:25-35

Gröhsler T, Oeberst R, Schaber M, Larson N, Kornilovs G (2013) Discrimination of western Baltic spring-spawning and central Baltic herring (Clupea harengus L.) based on growth vs. natural tag information. ICES J Mar Sci 70: 1108-1117

Hay DE (1986) Effects of delayed spawning on viability of eggs and larvae of Pacific herring. Trans Am Fish Soc 115:155-161

Holliday FGT, Blaxter JHS (1960) The effects of salinity on the developing eggs and larvae of the herring. J Mar Biol Assoc UK 39:591-603

Iles TD, Sinclair M (1982) Atlantic herring: stock discreteness and abundance. Science 215:627-633

* Illing B, Moyano M, Hufnagl M, Peck MA (2016) Projected habitat loss for Atlantic herring in the Baltic Sea. Mar Environ Res 113:164-173

Imsland AK, Foss A, Gunnarsson S, Berntssen MHG and others (2001) The interaction of temperature and salinity on growth and food conversion in juvenile turbot (Scophthalmus maximus). Aquaculture 198:353-367

* Iwamatsu T, Ishijima S, Nakashima S (1993) Movement of spermatozoa and changes in micropyles during fertilization in medaka eggs. J Exp Zool 266:57-64

Johannessen A, Skaret G, Langård L, Slotte A, Husebø A, Fernö A (2014) The dynamics of a metapopulation: changes in life-history traits in resident herring that cooccur with oceanic herring during spawning. PLOS ONE 9:e102462

Johannesson K, André C (2006) Life on the margin: genetic isolation and diversity loss in a peripheral marine ecosystem, the Baltic Sea. Mol Ecol 15:2013-2029

Jørgensen HBH, Hansen MM, Bekkevold D, Ruzzante DE, Loeschcke V (2005) Marine landscapes and population genetic structure of herring (Clupea harengus L.) in the Baltic Sea. Mol Ecol 14:3219-3234

Kanstinger P, Beher J, Grenzdörffer G, Hammer C, Huebert KB, Stepputis D, Peck MA (2018) What is left? Macrophyte meadows and Atlantic herring (Clupea harengus) spawning sites in the Greifswalder Bodden, Baltic Sea. Estuar Coast Shelf Sci 201:72-81

Klinkhardt M (1984) Zum Einfluss des Salzgehaltes auf die Befruchtungsfähigkeit des Laichen der Rügenschen Frühjahrsheringe. Fisch-Forsch 22:73-75

Lamichhaney S, Martinez Barrio A, Rafati N, Sundström G and others (2012) Population-scale sequencing reveals genetic differentiation due to local adaptation in Atlantic herring. Proc Natl Acad Sci USA 109:19345-19350

* Lamichhaney S, Fuentes-Pardo AP, Rafati N, Ryman N and others (2017) Parallel adaptive evolution of geographically distant herring populations on both sides of the North Atlantic Ocean. Proc Natl Acad Sci USA 114: E3452-E3461

Lande R (2009) Adaptation to an extraordinary environment by evolution of phenotypic plasticity and genetic assimilation. J Evol Biol 22:1435-1446

* Larmuseau MHD, Vancampenhout KIM, Raeymaekers JAM, Van Houdt JKJ, Volckaert FAM (2010) Differential modes of selection on the rhodopsin gene in coastal Baltic and North Sea populations of the sand goby, Pomatoschistus minutus. Mol Ecol 19:2256-2268

Lee CE, Kiergaard M, Gelembiuk GW, Eads BD, Posavi M (2011) Pumping ions: rapid parallel evolution of ionic regulation following habitat invasions. Evolution 65: 2229-2244

Martinez Barrio A, Lamichhaney S, Fan G, Rafati N and others (2016) The genetic basis for ecological adaptation of the Atlantic herring revealed by genome sequencing. eLife 5:e12081

* Meier HEM, Kjellström E, Graham LP (2006) Estimating uncertainties of projected Baltic Sea salinity in the late 21st century. Geophys Res Lett 33:L15705

Mjanger H, Svendsen BV, Senneset H, Fotland A, Mehl S, Salthaug A (2017) Håndbok for prøvetaking av fisk og krepsdyr. Institute of Marine Research, Bergen

* Momigliano P, Jokinen H, Fraimout A, Florin AB, Norkko A, Merilä J (2017) Extraordinarily rapid speciation in a marine fish. Proc Natl Acad Sci USA 114:6074-6079

Nilsson J, Gross R, Asplund T, Dove O and others (2001) Matrilinear phylogeography of Atlantic salmon (Salmo salar L.) in Europe and postglacial colonization of the Baltic Sea area. Mol Ecol 10:89-102

Nissling A, Westin L (1997) Salinity requirements for successful spawning of Baltic and Belt Sea cod and the potential for cod stock interactions in the Baltic Sea. Mar Ecol Prog Ser 152:261-271

Nissling A, Johansson U, Jacobsson M (2006) Effects of salinity and temperature conditions on the reproductive success of turbot (Scophthalmus maximus) in the Baltic Sea. Fish Res 80:230-238

* Pampoulie C, Slotte A, Óskarsson GJ, Helyar SJ and others (2015) Stock structure of Atlantic herring (Clupea harengus L.) in the Norwegian Sea and adjacent waters. Mar Ecol Prog Ser 522:219-230

Pinheiro JC, Bates DM (2000) Mixed-effects models in S and S-PLUS. Springer, New York, NY

* Poirier M, Listmann L, Roth O (2017) Selection by higherorder effects of salinity and bacteria on early life-stages of Western Baltic spring-spawning herring. Evol Appl 10: 603-615

Core Team (2017) R: a language and environment for statistical computing (version 3.4.1). R Foundation for Statistical Computing, Vienna, available at www.R-project.org

Kajasilta M, Laine P, Paranko J (2011) Current growth, fat reserves and somatic condition of juvenile Baltic herring (Clupea harengus membras) reared in different salinities. Helgol Mar Res 65:59-66

* Rosenthal H, Klumpp D, Willführ J (1988) Influence of sperm density and contact time on herring egg fertilization. J Appl Ichthyology 4:79-86

* Ruzzante DE, Mariani S, Bekkevold D, André C and others (2006) Biocomplexity in a highly migratory pelagic marine fish, Atlantic herring. Proc R Soc B 273:1459-1464

* Schneider RF, Meyer A (2017) How plasticity, genetic assimilation and cryptic genetic variation may contribute to adaptive radiations. Mol Ecol 26:330-350

Kilva FFG, Slotte A, Johannessen A, Kennedy J, Kjesbu OS (2013) Strategies for partition between body growth and reproductive investment in migratory and stationary populations of spring-spawning Atlantic herring (Clupea harengus L.). Fish Res 138:71-79

* Sinclair M, Power M (2015) The role of 'larval retention' in life-cycle closure of Atlantic herring (Clupea harengus) populations. Fish Res 172:401-414

* von Nordheim L, Kotterba P, Moll D, Polte P (2017) Impact of spawning substrate complexity on egg survival of Atlantic herring (Clupea harengus, L.) in the Baltic 
Sea. Estuaries Coasts 41:549-559

Vuorinen I, Hänninen J, Rajasilta M, Laine P and others (2015) Scenario simulations of future salinity and ecological consequences in the Baltic Sea and adjacent North

Sea areas-implications for environmental monitoring. Ecol Indic 50:196-205

Editorial responsibility: Jürgen Alheit (Guest Editor), Geestland, Germany
Yanagimachi R, Cherr GN, Pillai MC, Baldwin JD (1992) Factors controlling sperm entry into the micropyles of salmonid and herring eggs. Dev Growth Differ 34:447-461

Zuur A, Ieno EN, Walker N, Saveliev AA, Smith GM (2009) Mixed effects models and extensions in ecology with R. Springer, New York, NY

Submitted: September 1, 2017; Accepted: June 27, 2018

Proofs received from author(s): August 10, 2018 